Reprod. Nutr. Dévelop., 1982, 22 (3), 495-504.

\title{
Identification of androgen-dependent proteins synthesized in vitro by the ram epididymis
}

\author{
R. JONES, Suzanne FOURNIER-DELPECH $(*)$, S. A. WILLADSEN \\ A.R.C., Institute of animal Physiology, \\ Animal Research Station, \\ 307 Huntingdon Road, Cambridge CB3 OJO, U.K. \\ (*) Laboratoire de Fertilité mâle, I.N.R.A. \\ Nouzilly 37380 Monnaie, France
}

Summary. Protein synthesis has been investigated in different regions of the epididymis from normal rams, castrate rams, and castrate testosterone supplemented rams. Results show that there are few differences in the pattern of $\left[{ }^{35} \mathrm{~S}\right]$ methionine-labelled proteins synthesized in different regions of the normal epididymis despite the variation in the morphology of the epithelial cells lining the duct. Three androgen-dependent proteins of molecular weights 24000,64000 and $\sim 200000$ were identified. Testosterone did not stimulate protein synthesis in the proximal caput epididymidis (region 1-3), suggesting that testicular fluid is important in maintaining the activity of epididymal cells in this area.

\section{Introduction.}

Current evidence suggests that specific secretory proteins in the epididymis play an important role in the development of motility (Acott and Hoskins, 1978) and surface properties of spermatozoa during their post-testicular maturation stage (Kohane et al., 1980 ; Jones et al., 1980 b ; Voglmayr et al., 1980 ; Orgebin-Crist et al., 1981). It has been demonstrated in rats and rabbits that different proteins are synthesized and secreted in different morphological regions of the epididymis and that some of these proteins are regulated specifically by androgen (Lea et al., 1978; Brooks and Higgins, 1980; Faye et al., 1980; Moore, 1980 ; Jones et al., 1980 a, 1981). Previous studies on the ram epididymis have described the development of motility and fertilizing capacity by spermatozoa (Fournier-Delpech et al., 1979) and defined a number of surface changes on the plasma membrane (Courtens and Fournier-Delpech, 1979; Hammerstedt et al., 1979). The objective of the work reported in this communication was to investigate the synthesis, secretion and hormonal regulation of proteins in different areas of ram epididymis as a preliminary step towards examining their interaction with spermatozoa. 


\section{Material and methods.}

All chemicals, purchased from sources described previously (Jones et al., 1980 a), were of the highest purity available commercially.

A. Preparation of animals. - Adult cross-bred Suffolk rams were used throughout these experiments and all surgical procedures were carried out with general anaesthesia. The animals were electroejaculated before surgery and only those showing motile spermatozoa (60-90 p. 100) were included in the experiment. They were assigned randomally to 3 groups : group 1 ( 2 normal rams), group 2 ( 3 rams castrated for 6 weeks) and group 3 ( 3 rams castrated for 6 weeks then given $200 \mathrm{mg}$ of testosterone propionate/2nd day, intramuscularly, for a further 6 weeks). Groups 1 and 2 received identical injections of solvent without testosterone. After the last injection, the epididymides were removed and the tissues, placed on ice, were sub-divided into the following regions : efferent ducts (ED), proximal caput (region 1), distal caput (region 2/3), proximal corpus (region 4), middle corpus (region 5), distal corpus (region 6), cauda (region 7); this subdivision of the epididymis (fig. 1) approximates the morphological areas described by Nicander (1958, 1979). Cauda epididymidal plasma (CEP) was recovered from normal epididymides by retroperfusion via the vas deferens with phosphate-buffered saline (PBS), $\mathrm{pH} 7.4$, preceded by a small air bubble to prevent dilution.

B. In vitro-labelling of protein $\left.L-{ }^{35} S\right]-$ methionine. - The tissues were washed in cold PBS and minced; the minces were washed twice to remove the spermatozoa and epididymal fluid, and $30 \mathrm{mg}$ of wet tissue was placed in $1 \mathrm{ml}$ of Dulbecco's modified Eagle's medium 199 containing $15 \mu \mathrm{Ci}$ of L-[ $\left.{ }^{35} \mathrm{~S}\right]$-methionine. The vials were gassed for $2 \mathrm{~min}$ with air $/ \mathrm{CO}_{2}(19.1)$ then incubated at $33^{\circ} \mathrm{C}$ for

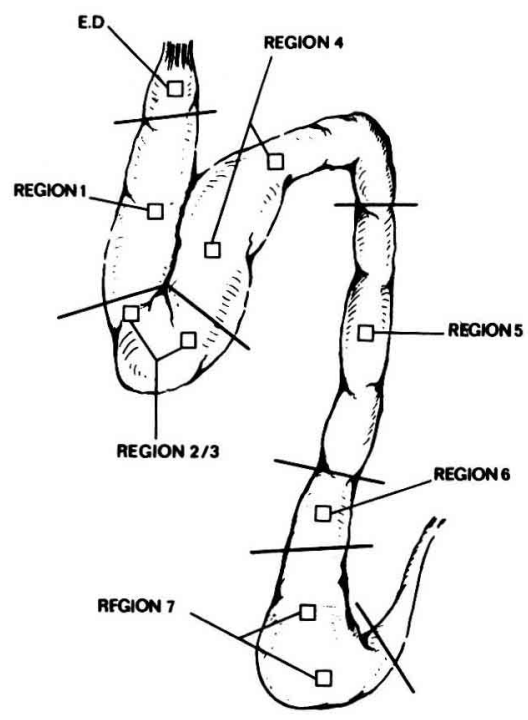

FIG. 1. - Diagram of ram epididymis illustrating the sub-divisions used in these experiments. Representative areas of tissue removed from each region were minced, and the aliquots incubated in vitro with $\left[{ }^{35} \mathrm{~S}\right]$-methionine as described in Materials \& Methods. 
$2 \mathrm{~h}$. Incubations were stopped by the addition of $1 \mathrm{ml}$ of an ice-cold solution of sucrose buffer $10,7 \mathrm{M}$ sucrose, $6 \mathrm{mM} \mathrm{MgCl}, 0.5 \mathrm{M}$ Tris- $\mathrm{HCl}, \mathrm{pH} 7.5,50 \mathrm{mM}$ $\mathrm{KCl}, 2$ p. 100 Triton $\mathrm{X}-100$ ). Preliminary experiments showed that incorporation of radiolabel into acid-insoluble protein was linear for at least 2 hours of incubation.

\section{Analysis of proteins.}

1. - Quantitation of labelled proteins. Tissues, homogenized with a teflon homogenizer $(500 \mathrm{rpm})$ for $40 \mathrm{sec}$, were centrifuged at $1000 \times \mathrm{g}$ for $15 \mathrm{~min}$ and the aliquots from the postnuclear supernatant were mixed with excess ice-cold trichloracetic acid (5 p. 100). The precipitated proteins were collected on glassfibre filters (GC/Whatman) and their radioactivity was counted in a 5-ml Packard scintillator 299 cocktail in a Packard liquid scintillation spectrometer.

\section{2. - Analytical electrophoresis.}

a) Non-denaturing polyacrylamide gels. Aliquots $(500 \mu \mathrm{l})$ of post-nuclear supernatants were dialysed against $10 \mathrm{mM}$ Tris-glycine buffer, $\mathrm{pH} 8,3$, and lyophilised. The samples were dissolved in $50 \mu \mathrm{l}$ of distilled water and a volume containing $40000 \mathrm{cpm}$ was submitted to electrophoresis on slab gels $(10 \mathrm{~cm} \times 16 \mathrm{~cm} \times 0.2 \mathrm{~cm})$ containing 7 p. $100(\mathrm{v} / \mathrm{v})$ polyacrylamide according to the conditions of Davis (1964). The gels were fixed and stained for $1 \mathrm{~h}$ with 0.05 p. $100(\mathrm{w} / \mathrm{v})$ Coomassie Brilliant Blue in an aqueous solution of 40 p. 100 $(\mathrm{v} / \mathrm{v})$ methanol and 7 p. $100(\mathrm{v} / \mathrm{v})$ acetic and destained overnight in the same solvent without dye.

b) Denaturing polyacrylamide gels. Postnuclear supernatants were dialysed against $6 \mathrm{mM}$ Tris-glycine buffer, pH 7.5, containing 0.1 p. $100(\mathrm{w} / \mathrm{v})$ SDS, lyophilised and dissolved in one-tenth volume of distilled water containing 1 p. $100(\mathrm{v} / \mathrm{v}) \quad \beta$-mercaptoethanol. After heating for $2 \mathrm{~min}$ at $100^{\circ} \mathrm{C}$, aliquots $(40000 \mathrm{cpm}$ ) were applied to $15 \mathrm{p} .100(\mathrm{w} / \mathrm{v})$ polyacrylamide slab gels containing SDS as described previously (Jones et al., 1980 a). Proteins were stained with Coomassie Brilliant Blue.

3. - Detection of labelled proteins. Labelled proteins were detected by fluorography (Bonner and Laskey, 1974) on pre-flashed film (Kodak X-OMAT H) and quantified by densitometry using an integrating densitometer.

\section{Results.}

A. - Protein synthesis at different levels of normal ram epididymis. - The analysis of $\left.{ }^{35} \mathrm{~S}\right]$-methionine-labelled proteins on denaturing polyacrylamide gels followed by fluorography revealed that radioactivity was incorporated into a wide range of polypeptides in all regions of the epididymis (fig. 2). The pattern of labelled polypeptides was similar in each region and the only differences of note 
(a)

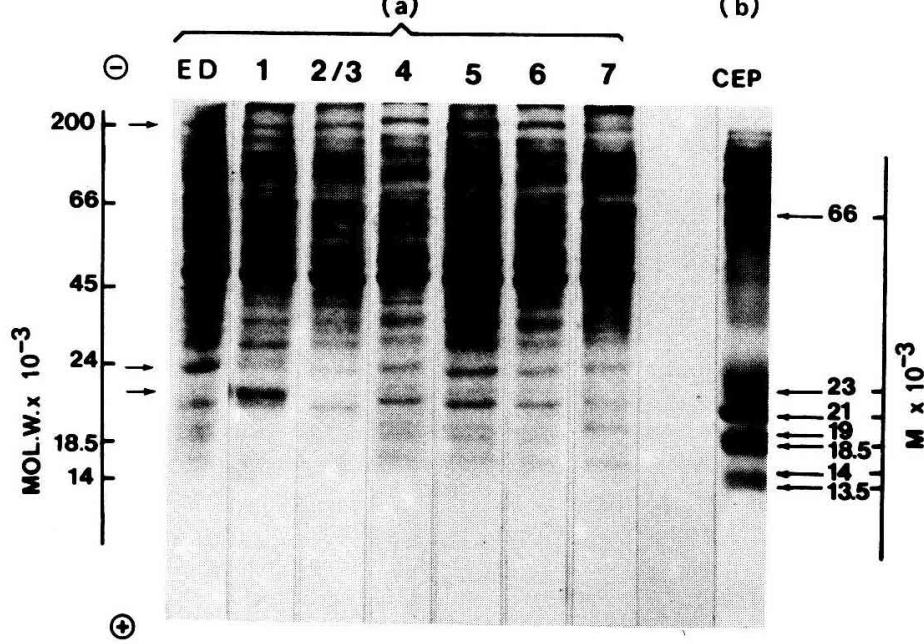

FIG. 2. - (a) Fluorograph of $\left[{ }^{35} \mathrm{~S}\right]-$ methionine-labelled proteins synthesized in efferent ductules (ED) and in different regions (2-7) of the normal ram epididymis after separation of postnuclear supernatants on denaturing polyacrylamide ge/s $(-=23 \mathrm{~K})$; (b) Coomassie Blue stain of proteins in cauda epididymal plasma (CEP) from normal ram separated on denaturing polyacrylamide gel.

were in minor polypeptides. For example, a polypeptide of $23000 \mathrm{MW}(23 \mathrm{~K})$ was present in region 1, but was poorly represented in the other regions ; a polypeptide of approximately $24000 \mathrm{MW}(24 \mathrm{~K})$ was labelled in the ED and regions 4-7, but was hardly detectable in regions $1-2 / 3$. Fig. 2 b shows, under identical electrophoretic conditions, the pattern of proteins (stained with Coomassie Blue) in the secreted luminal cauda epididymis plasma (CEP) of normal rams. At least 10 high-molecular weight polypeptides $(>66000)$ were present but the major low-molecular weight polypeptides had molecular weights of 13500,14000 , $18500,19000,21000$ and 23000 . It was noticeable that several major polypeptides synthesized by the tissue were poorly represented in the CEP, particularly in the range of 24000 to $66000 \mathrm{MW}$.

B. - Effects of castration and testosterone supplementation. - After castration, the incorporation of $\left.{ }^{35} \mathrm{~S}\right]$-methionine into total acid insoluble protein decreased significantly $(P<0,05)$ in all regions of the epididymis to between 20 and 35 p. 100 of that of the controls (fig. 3). After testosterone supplementation, the incorporation of labelled precursor into protein was stimulated in some areas but not in others. Thus, it was restored to near normal level in region 4 and was higher than in castrates in regions 5,6 , and 7 , but was not stimulated in the proximal areas of the epididymis (ED, regions 1 and 2/3). However, these differences caused by testosterone supplementation were not statistically significant $(P<0.05)$ due to the small number of rams in each group.

The separation of postnuclear supernatants on denaturing polyacrylamide gels followed by fluorography revealed 2 polypeptides whose synthesis was reduced by castration but stimulated by testosterone. In castrates, the 


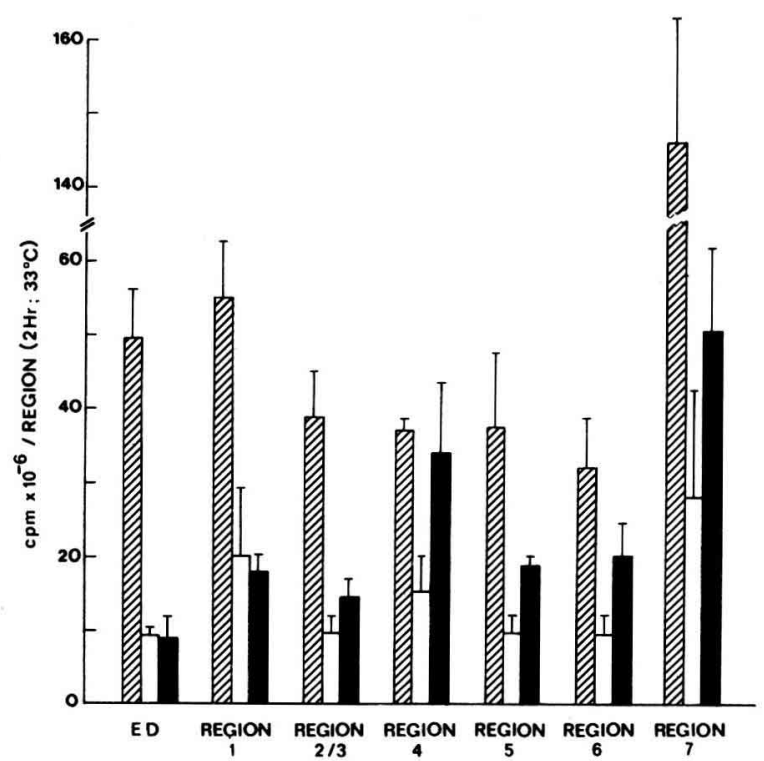

FIG. 3. - Incorporation of $\left.{ }^{35} \mathrm{~S}\right]$-methionine into total acid-insoluble protein epididymal region $/ 2 \mathrm{hr}$ of incubation in normal rams ( castrated rams (ㅁ), and castrated testosterone-induced rams $(\boldsymbol{E})$. Values are means \pm SEM.

incorporation of radioactivity into a high-molecular weight protein, $\sim 200000$ $(\sim 200 \mathrm{~K})$, was $10-15 \mathrm{p} .100$ of that in animals supplemented with testosterone (fig. 4). This pattern was found in all regions of the epididymis but was most

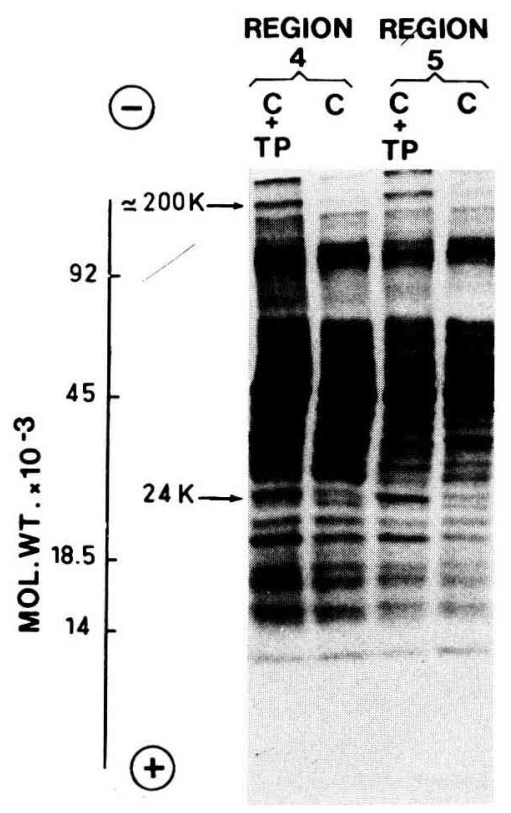

FIG. 4. - Fluorograph of $\left.{ }^{35} \mathrm{~S}\right]$-methionine-labelled proteins synthesized in regions 4 and 5 of castrate rams (C) and castrate testosteronesupplemented rams (C + TP). 
evident in regions 4,5 , and 6 . Similarly, the synthesis of a polypeptide of $24000 \mathrm{MW}$ in castrates was 30-40 p. 100 of that found after testosterone treatment, and this pattern occurred throughout the distal regions of the epididymis.

However, on non-denaturing gels stained with Coomassie Blue, a prealbumin epididymal-specific (PES ; Fournier-Delpech, 1968; Fournier-Delpech et al., 1973) protein was present in the postnuclear supernatants from normal and testosterone-stimulated animals but absent in those of castrates (fig. 5). When the area of the gel containing the PES protein was cut out and the protein electrophoresed on denaturing gels, it was found to have a molecular weight of 64000 . This protein was present in all areas of the epididymis of testosteronesupplemented animals but was most prominent in regions 5,6 , and 7 . Fluorographs revealed that the PES protein was poorly labelled relative to more basic proteins, although it contained 3 to 4 times more radioactivity las measured by densitometry) in testosterone-treated animals than in castrates.

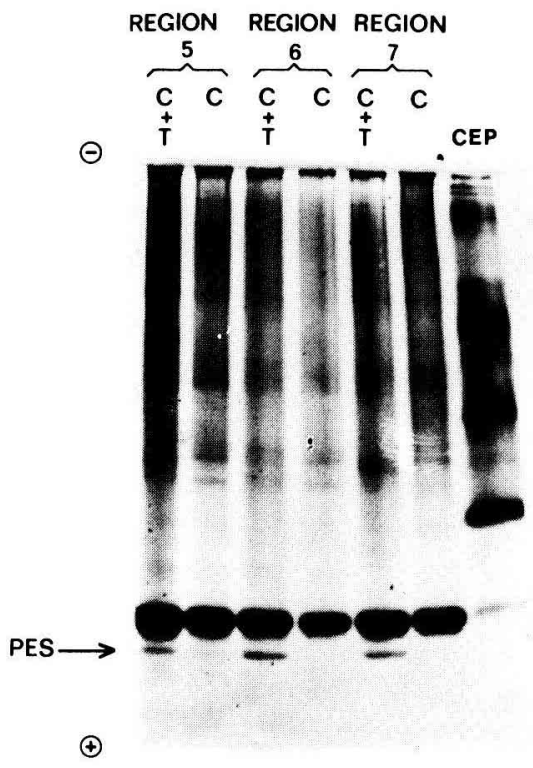

FIG. 5. - Coomassie Blue stain of proteins in postnuclear supernatant fractions of epididymal regions 5, 6 and 7 from castrated rams (C) and castrated testosterone-induced rams (C $+\mathrm{TP})$ after separation on non-denaturing polyacrylamide gel. Cauda epididymal plasma (CEP) from normal rams is shown for comparison. PES = prealbumin epididymal specific protein which had a molecular weight of $64 \mathrm{~K}$.

\section{Discussion.}

Contrary to the situation in rats and rabbits, there does not appear to be any substantial variation in the type of proteins synthesized in different regions of the normal ram epididymis. Therefore, in this species, morphological dissimilarities in the epithelial cells of the duct (Nicander, 1958) are not reflected by differences in their protein-synthesizing capacity, assuming that the epithelial cells are more active in protein synthesis than muscle or connective tissue cells. Furthermore, 
with one possible exception, the major secreted proteins in the luminal plasma collected from the cauda epididymidis (mol. wts. ranging from 13500 to 23000 ) were not heavily labelled when tissue minces were incubated in vitro with [ $\left.{ }^{35} \mathrm{~S}\right]-$ methionine. This suggests that either these proteins are synthesized at a very low rate or that they contain few methionine residues and hence label poorly with this precursor. The only exception was the $23 \mathrm{~K}$ protein, found principally in region 1 , which incorporated relatively more $\left.{ }^{35} \mathrm{~S}\right]-$ methionine than the other low mol.wt. polypeptides.

Most of the major proteins in the CEP appear to be anteprealbumin proteins since no prealbumin was detected on non-denaturing gels at $\mathrm{pH}$ 8-9 (Davis, 1964). Again, this is different from the situation in rodents where highly acidic prealbumin proteins are the major components of the luminal secretion (Jones et al., 1980 a, 1981 ; Moore, 1980). Fig. 5 also shows only a trace of albumin in the CEP, whereas in tissue homogenate:s, it was the major protein staining with Coomassie Blue. The albumin in tissue homogenates, derived principally from lymph and traces of blood remaining in the minces, indicates that a permeability barrier exists between the blood and the epididymal lumen. That this bloodepididymal barrier is likely to be found at the level of the epididymal epithelium is suggested by the observation in rabbits that, after castration when the epithelial cells lining the epididymal duct atrophy, large amounts of serum albumin appear in the CEP which can be prevented by administering testosterone (Jones and Dott, 1980).

The synthesis of two Triton-soluble components (24K and 200K) was stimulated preferentially by testosterone, as revealed by fluorography of denaturing polyacrylamide gels. However, neither of these polypeptides were major labelled proteins. We also observed a $64 \mathrm{~K}$ protein on non-denaturing gels stained with Coomassie Blue that was absent in castrates but present after testosterone stimulation. The fact that this protein was not detected on fluorographs of denaturing gels suggests that it has a low rate of synthesis. If so, then the long period of treatment of castrates with testosterone would have allowed significant quantities to have accumulated in the tissue. The absence of this protein from the CEP of normal rams also suggests that it is a non-secreted protein. An alternative explanation is that it may be removed from the CEP by interaction with the sperm plasma membrane. An examination of CEP from castrate-testosterone supplemented animals might resolve this problem.

The failure of testosterone to stimulate protein synthesis in the proximal regions of the caput epididymidis may be related to the dependence of this area on testicular fluid. In this respect, the ram appears to be similar to the rat, rabbit and hamster (Jones et al., 1980 a ; Jones, Fournier-Delpech and Von Glos, unpublished observations) in which a decline in the synthesis of certain proteins has been found after occlusion of the efferent ductules. However, in these experiments it was not possible to determine whether the effects were caused by a real decrease in protein synthesis per epithelial cell or by a loss of epithelial cells. Whatever the reason, it would appear that factors in testicular fluid, e.g. androgen-binding protein (Jegou et al., 1979) or growth factors (Feig et al., 
1980), are required to stimulate the full activity of the epithelial cells in the proximal regions of the mammalian epididymis.

\section{Conclusions.}

Three androgen-dependent proteins have been identified in the epididymis of the ram. Their rates of synthesis and secretion were low relative to the situation in other species but they may serve as useful markers for investigating the effects of androgens and testicular fluid in that tissue.

Acknowledgements. - The authors wish to thank Dr. M. Courot for his assistance in the preparation of this manuscript, Drs. E. J. C. Polge and M. T. Hochereau de Reviers for encouragement and $M$. Terriot for preparing the illustrations. We also grateful to $\mathrm{Dr}$. H. M. Dott for assistance with the animals and to Mr K. I. von Glos for technical assistance. We wish to thank the CNRS for providing one of us (S. Fournier-Delpech) with financial support.

Résumé. Cette publication rapporte la caractérisation in vitro chez le bélier de composés protéïques synthétisés par l'épididyme sous l'action de la testostérone.

L'étude a porté sur 2 animaux non traités (Témoins), 3 animaux castrés depuis 6 semaines (Castrats) et 3 animaux castrés depuis 6 semaines et recevant une injection de $200 \mathrm{mg}$ de propionate de testostérone tous les 2 jours par voie intramusculaire (Castrats supplementes). Les coupes de tissus $(30 \mathrm{mg})$ ont été incubées $2 \mathrm{~h}$ à $33^{\circ} \mathrm{C}$ en présence de $15 \mu \mathrm{Ci}$ de $\mathrm{L}-\left[{ }^{35} \mathrm{~S}\right]$ methionine (Jones et al., 1980a) : les protéïnes marquées ont été quantifiées par le taux de radioactivité du précipité TCA lavé et analysé par fluorographie après séparation électrophorétique en gel de polyacrylamide avec SDS là 15 p. 100 d'acrylamide) et en gel non dénaturant à 7 p. 100 d'acrylamide - à pH 8-3.

La castration diminue considérablement la quantité de $\mathrm{L}^{\left[{ }^{35}\right]}$ methionine incorporée ; entre -60 et $\_80$ p. 100 selon les régions. Après 6 semaines de supplémentation hormonale, la radioactivité incorporée dans les protéines n'est pas affectée dans l'épididyme proximal alors qu'elle a doublé dans les tissus de l'épididyme médian et distal ; où elle reste cependant inférieure à la normale.

On met en évidence 2 sous unités polypeptidiques androgène dépendantes de poids moléculaire $24000(24 \mathrm{~K})$ et environ $200000(\sim 200 \mathrm{~K})$ en électrophorèse avec SDS. La régulation de $\sim 200 \mathrm{~K}$ par la testostérone circulante est claire. Elle n'est pas suffisante pour expliquer la synthèse préférentielle de $24 \mathrm{~K}$ par l'épididyme antérieur où une voie $\mathrm{d}^{\prime}$ action directe par la voie de résorption de l'ABP est envisagée.

On note la synthèse sous la régulation de la testostérone d'une globuline migrant en position préalbumine en gel non dénaturant analogue à celle qui est secrétée par l'épididyme, de poids moléculaire 64000 (64K), et fixée par les spermatozoïdes chez les rongeurs.

On considère les 3 composés $200 \mathrm{~K}, 24 \mathrm{~K}$ et l' $\alpha$ globuline préalbumine (64K) comme des marqueurs moléculaires de l'activité de l'épididyme régulée par les androgènes qui pourraient être en relation avec la maturation des spermatozoïdes. 


\section{Références}

ACOTT T. S., HOSKINS D. D., 1978. Bovine forward motility proteins. J. biol. Chem., 253, 6744-6750.

BONNER W. M., LASKEY R. A., 1974. A film detection method for tritium-labelled proteins and nucleic acids in polyacrylamide gels. Eur. J. Biochem., 46. 83-88.

BROOKS D. E., HIGGINS S. J., 1980. Androgen-controlled specific proteins in rat epididymis. J. Reprod. Fert., 59, 363-375.

COURTENS J. L., FOURNIER-DELPECH S., 1979. Modifications in the plasma membranes of epididymal ram spermatozoa during maturation and incubation in utero. J. ultr. Res., 68, 136-148.

DAVIS F. J., 1964. Disc electrophoresis. Ann. N.Y. Acad. Sci, 121, 404427.

D'AGOSTINO A., JONES R., WHITE R., PARKER M. G., 1980. Androgenic regulation of messenger RNA in rat epididymis. Biochem. J., 190, 505-512.

FAYE J. C., DUGUET L., MAZZUCHA M., BAYARD F., 1980. Purification, radio-immunoassay and immunochemical localization of a glycoprotein produced by the rat epididymis. Biol. Reprod., 23, 423-432.

FEIG L. A., BELLVE A. R., ERICKSON N. H., KLAGSBURN M., 1980. Sertoli cells contain a mitogenic polypeptide. Proc. nat. Acad. Sci. USA, 77, 4774-4778.

FOURNIER-DELPECH S., 1968. Electrophorèse des protéines du tractus génital du rat. Présence dans le sperme épididymaire d'une glycoprotéine migrant vers l'anode à $\mathrm{pH} 8.45$. C.R. Soc. Biol., 162, 558-562.

FOURNIER-DELPECH S., BAYARD F., BOULARD C., 1973. Contribution à l'étude de la maturation du sperme. Etude d'une protéine acide chez le rat. C.R. Soc. Biol., 167, 1989-1996.

FOURNIER-DELPECH S., COLAS G., COUROT M., ORTAVANT R., BRICE G., 1979. Epididymal sperm maturation in the ram: motility, fertilizing ability and embryonic survival. Ann. Biol. anim. Bioch. Biophys., 19, 597-605.

HAMMERSTEDT R. H., KEITH A. D., HAY S., DE LUCA N., AMANN R. P., 1979. Changes in ram sperm membranes during epididymal transit. Arch. Biochem. Biophys., 196, 7-12.

JEGOU B., DACHEUX J. L., GARNIER D. H., TEROUI M., COLAS G., COUROT M., 1979. Biochemical and physiological studies of androgen-binding protein in the reproductive tract of the ram. J. Reprod. Fert., 57, 311-318.

JONES R., DOTT H. M., 1980. Changes in luminal plasma and disappearance of spermatozoa from the ligated cauda epididymidis of the androgen-deficient rabbit. J. Reprod. Fert., 60, 65-72.

JONES R., BROWN C. R., VON GLOS K. I., PARKER M. C., 1980a. Hormonal regulation of protein synthesis in the rat epididymis. Biochemical J., 188, 667-676.

JONES R., VON GLOS K. I., BROWN C. R., 1980b. The synthesis of a sperm-coating protein in the initial segment of the rat epididymis is stimulated by factors in testicular fluid. IRCS J. Med. Sci., 8, 56.

JONES R., VON GLOS K. I., BROWN C. R., 1981. Characterization of hormonally regulated secretory proteins from the caput epididymidis of the rabbit. Biochem. J., 196, 105-114.

KOHANE A. C., ECHEVERRIA H. C. G., PINEIRO L., BLAQUIER J. A., 1980. Interaction of protein of epididymal origin with spermatozoa. Biol. Reprod., 23, 737-742.

LEA O. A., PETRUSZ P., FRENCH F. S., 1978. Purification and localization of acidic epididymal glycoprotein (AEG) : A sperm coating antigen secreted by the rat epididymis. Int. J. Androl., Suppl. 2, Part 2, 592-605.

MOORE H. D. M., 1980. Localization of specific glycoproteins secreted by the rabbit and hamster epididymis. Biol. Reprod., 22, 705-718.

NICANDER L., 1958. Studies on the regional histology and cytochemistry of the ductus epididymis in stallions, rams and bulls. Acta. morph. neerl. scand., 1, 337-362.

NICANDER L., 1979. Fine structure of principal cells in the initial segment of the epididymal duct in the ram. Zbl. Vet. Med. C. Anat. Histol. Embryol., 8, 318-330. 
ORGEBIN-CRIST M. C., OLSON G. E., DANZO B. J., 1981. Factors influencing maturation of spermatozoa in the epididymis. In P. FRANCHIMONT, C. CHANNING, Intragonadal regulation of reproduction. Academic Press. 393-417.

VOGLMAYR J. K., FAIRBANKS G., JACKOWITZ M. A., COLELLA J. R., 1980. Post-testicular development changes in the ram cell surfaces and their relationship to luminal fluid proteins of the reproductive tract. Biol. Reprod., 22, 655-667. 